\title{
The Effect Of Sexual Education Of Prevention Sexual Harassment In Children Age Schools In Sd Darul Ulum Bungurasih Waru Sidoarjo
}

\author{
Nur Hidaayah ${ }^{1}$, Rizqa Fadhilatul Faeiqah ${ }^{2}$ \\ \{nurhid@unusa.ac.id,rizqa.ns15@student.unusa.ac.id\} \\ ${ }^{12}$ Department of Nursing, Nahdlatul Ulama University Surabaya
}

\begin{abstract}
Children who had sexual abused are generally due to not knowing the boundaries of a body that cannot be seen or touched by others even sometimes unaware that they are being sexually abused. Tihis study aims to analyze the influence of sexual education on the prevention of sexual abuse in school-age children at SD Darul Ulum Bungurasih Waru Sidoarjo. The design of research is pre-experimental analytic using one-group pre-post design pattern, the population of all grade II and III students with 133 people with a samples of 100 respondents selected using techniques proportionate stratified random sampling. Independent variables that is sexual education and dependent variables that is the prevention of sexual abuse, with instruments in the form of questionnaires, and analyzed using the Wilcoxon test signed rank test with the significance of $\alpha$ $=0.05$. Obtained results of respondent's behaviour against the sexual abuse prevention value of pre-test $43 \%$ negative behavior and post-test $95 \%$ positive behavior. The results of data analysis of $\rho(0.00)<\alpha(0.05)$, meaning there is an influence of sexual education on the prevention of sexual abuse in school-age children at SD Darul Ulum BungurasihWaru Sidoarjo. Students who had gained sexual education have positive behaviors for sexual abuse prevention, which is why sexual education is important to change negative behaviour to positive against the prevention of sexual abuse.
\end{abstract}

Keywords: Sexual education, sexual abuse prevention, school-age children

\begin{abstract}
Abstrak: Anak yang mendapatkan pelecehan seksual umumnya karena belum mengetahui batasan bagian tubuh yang tidak boleh dilihat atau disentuh oleh orang lain bahkan terkadang tidak sadar bahwa mereka dilecehkan. Penelitian bertujuan menganalisis pengaruh edukasi seksual terhadap pencegahan pelecehan seksual pada anak usia sekolah di SD Darul Ulum Bungurasih Waru Sidoarjo. Desain penelitian adalah analitik dengan rancangan pre-Eksperimental menggunakan pola one-group pre-post design, populasinya seluruh siswa kelas II dan III sebanyak 133 orang dengan besar sampel 100 responden yang dipilih menggunakan teknik proportionate stratified random sampling. Variabel independen yaitu edukasi seksual dan variabel dependen yaitu pencegahan pelecehan seksual, dengan instrumen berupa kuesioner, dan dianalisis menggunakan uji wilcoxon signed rank test dengan kemaknaan $\alpha=0,05$.
\end{abstract}


Didapatkan hasil perilaku responden terhadap pencegahan pelecehan seksual nilai pre-test $43 \%$ perilaku negatif dan post-test $95 \%$ perilaku positif. Hasil analisa data nilai $\rho(0,00)<\alpha(0,05)$, artinya ada pengaruh edukasi seksual terhadap pencegahan pelecehan seksual pada anak usia sekolah di SD Darul Ulum Bungurasih Waru Sidoarjo. Siswa yang telah mendapat edukasi seksual memiliki perilaku positif terhadap pencegahan pelecehan seksual, oleh karena itu penting dilakukan edukasi seksual guna merubah perilaku negatif menjadi positif terhadap pencegahan pelecehan seksual.

Kata Kunci: Edukasi seksual, pencegahan pelecehan seksual, anak usia sekolah

\section{Inttroductrion}

The occurrence of sexual abuse in children can be caused because the child has not received sexual education so that the child does not know that his body must be protected and protected, the child does not know the limits of body parts that should not be seen or touched by others. Cases of sexual harassment in Indonesia have always been the subject of discussion in various media, these unwanted events occur suddenly and do not know the victims. This phenomenon is like an iceberg that looks small from the outside but big inside, there are facts hidden inside. Often those who commit these crimes are school security officers, teachers, neighbors, and even their own families. This can occur because of easy access to pornographic material that makes the perpetrators practice directly to their victims, victims of sexual crimes who tend to do the same thing later on to others, namely becoming perpetrators or predators of children, lack of knowledge of children and families will provide opportunities for perpetrators to commit crimes, and legal norms that have not provided a deterrent effect so that perpetrators do not feel deterrent and allow them to commit their crimes again (Chomaria, 2014). Introducing sexual things to children is something that is very difficult to do for most parents. In fact, this must be conveyed so that children get the correct information. Especially in today's world where the flow of information is so swift and does not always provide the right information. Sexual education meant here is to teach children, direct them, and express frankly to him about matters relating to sex as well as those related to their roles and duties (Nashih 'Ulwah, 2011). Sex education aims to provide a correct understanding of sexuality, therefore the presentation is done not in a way that arouses passion.

Statistically, according to UNICEF around 120 million children around the world have been sexually abused. It can be seen from the data in the United States which reports that 75,000 cases of rape occur each year, and $90 \%$ of them are experienced by women who have racial similarities with the perpetrators and $76 \%$ are known by victims (Indrayana, 2017). According to KPAI there was an increase in child sexual abuse from 2013 with a total of 590 cases, an increase of $100 \%$ in 2014 with a total of 1,217 cases. According to the Chairman of Komnas PA (2017) Arist Merdeka Sirait stated that in 2016, the number of sexual harassment was higher than the previous year, which was 3,339 cases. According to KPAI commissioner in the field of education, Retno Listyarti (2018) in East Java in 2017 there were 393 cases (child victims), and at the beginning of 2018 entering the end of February the number of child victims was 117.

Kasat Reskrim Polresta Sidoarjo Kompol Muhammad Harris, cases that occurred in Sidoarjo decreased in the last 3 years, as has been recorded: in 2015 there were 46 cases, in 
2016 there were 44 cases, in 2017 there were 43 cases, and in 2018 in the first two months occurred 9 cases. During the initial data collection conducted by researchers in October 2018 at SD Darul Ulum Bungurasih Waru Sidoarjo by interviewing 10 students randomly about whether they had experienced something unpleasant, such as being treated improperly by someone they did not know or someone they knew , 6 people out of 10 children answered that they have experienced this.

There are several factors that influence the occurrence of sexual abuse in children include: the orientation of sexual attraction towards children (pedophilia), the influence of pornographic mass media (people who are exposed to pornography will reflect what they see in the form of concrete actions towards those around them ), and lack of understanding or lack of knowledge of children about sexuality issues (Fauzi'ah, 2016). Often a child is targeted as the initial target of sexual harassment because the child is always in a weaker and helpless position. Cases of child sexual abuse have a serious impact that will be received in the future, so that there are no similar incidents or subsequent victims, it is important for a child to be given sexual education as a preventative measure. Giving an understanding of sex to schoolage children is expected so that children can get the right information (Jatmikowati, 2015).

Most Indonesians consider sexual education to be a taboo subject. As stated by Lestari (2017) that sexual education has an influence on early childhood related to the mindset and ability of children, to help them protect themselves from sexual offenders. From the description of the events above the researchers felt interested in conducting research on "The effect of sexual education on the prevention of sexual harassment in school-age children at SD Darul Ulum Bungurasih Waru Sidoarjo". Researchers will provide material on the introduction of sexual education to school-age children using audiovisual media.

\section{Method}

This type of research is analytic with pre-experimental design using one-group pre-post design design patterns. This type of research seeks to reveal the effect of cause and effect by involving a group of subjects. In this design, observations were made 2 times, namely before giving the intervention, then observed again after giving the intervention.

The population in this study were students of SD Darul Ulum Bungurasih Waru Sidoarjo by 133 students (II A were 33 people, II B were 32 people, III A were 34 people, and III B were 34 people) with criteria:

1. Inclusion Criteria

a. Students from grade II and III at SD Darul Ulum Bungurasih Waru Sidoarjo.

b. Darul Ulum Bungurasih Waru Sidoarjo Elementary School students who are willing to participate in research.

2. Exclusion Criteria

a. Darul Ulum Bungurasih Waru Sidoarjo elementary school students who were sick at the time of the research.

b. Darul Ulum Bungurasih Waru Sidoarjo Elementary School students who were not in class at the time of the study.

The sample size in this study was determined based on a formula of 100 respondents. The method of taking samples with probability sampling method with proportionate stratified random sampling technique is proportional random sampling with stratification. And determined the sample from each class based on the formula that is 24 respondents from class 
II A, 24 respondents from class II B, 26 respondents from class III A, and 26 respondents from class III B. The independent variable in this study is sexual education and the dependent variable namely prevention of sexual harassment by using instruments in the form of questionnaires. Data collection techniques with primary data through questionnaires by respondents. Data processing editing, scoring, coding, processing, cleaning, tabulating, to determine the effect of sexual education on the prevention of sexual harassment in schoolaged children at SD Darul Ulum Bungurasih Waru Sidoarjo by using the Wilcoxon signed rank test using the SPSS for Windows program with significance level $\alpha$. $=0.05$.

\section{Results and Discussion}

1. General Data

General data includes the characteristics of age, sex, and education / class of students at Darul Ulum Bungurasih Waru Sidoarjo Elementary School.

a. Characteristics of respondents based on age.

Table 1 frequency distribution of respondents based on the age of elementary school respondents Darul Ulum Bungurasih Waru Sidoarjo.

Source: Primary Data, June 2019

\begin{tabular}{ccc}
\hline Age (Year) & Frekuency & Persentase $(\%)$ \\
\hline 7 & 4 & 4,0 \\
8 & 38 & 38,0 \\
9 & 39 & 39,0 \\
10 & 19 & 19,0 \\
Total & 100 & 100 \\
\hline
\end{tabular}

Table 1 shows that out of 100 respondents almost half (39.0\%) were 9 years old.

b. Characteristics of respondents by sex.

Table 2 the frequency distribution of respondents based on the gender of SD Darul Ulum Bungurasih Waru Sidoarjo students.

\begin{tabular}{ccc}
\hline Gender & Frekuency & Persentase (\%) \\
\hline Male & 43 & 43,0 \\
Famale & 57 & 57,0 \\
Total & 100 & 100 \\
\hline
\end{tabular}

Source: Primary Data, June 2019

Table 2 shows that of the 100 respondents most (57.0\%) were female.

\section{Special Data}

Specific data describes the characteristics of respondents based on the behavior of respondents before and after the provision of sexual education.

a. The results of filling out the questionnaire by respondents before and after sexual education. 
Table 3 distribution of the results of filling out the questionnaire by respondents before and after the provision of sexual education at SD Darul Ulum Bungurasih Waru Sidoarjo.

\begin{tabular}{cccccc}
\hline & $\mathrm{N}$ & $\mathrm{Min}$ & $\begin{array}{c}\mathrm{Ma} \\
\mathrm{x}\end{array}$ & Mean & Std. Dev \\
\hline Pre & 100 & 1 & 12 & 7,03 & 2,167 \\
Post & 100 & 6 & 12 & 11,35 & 0,978 \\
\hline
\end{tabular}

Source: Primar Data, June 2019

Table 3 shows that prevention efforts carried out by respondents in the from of known behaviors through the results of filling out the questionnaire prior to sexual education are obtained a minimum value $(\mathrm{min})$ of 1 , a maximum value $(\max )$ of 12 , average data (mean) of 7,03 , while the results of filling out the questionnaire after giving sexual education were obtained a minimum value (min) of 6 , a maximum value $(\max )$ of 12 , and an average (mean) of 11.35 .

b. The results of data on age crosstabulation with respondent behavior prior to sexual education

Table 4 data on age crosstabulation with respondent behavior before sexual education.

\begin{tabular}{lcccccc}
\hline \multirow{2}{*}{ Age } & \multicolumn{3}{c}{ Respondent Behavior } & \multicolumn{2}{c}{ Total } \\
\cline { 2 - 5 } & \multicolumn{2}{c}{ Positive } & \multicolumn{2}{c}{ Negative } & \multicolumn{2}{c}{} \\
\cline { 2 - 6 } & Frequency & Presentase & Frequency & Persentase & Frekuency & Persentase \\
\hline 7Year & 4 & $4.0 \%$ & 0 & $0.0 \%$ & 4 & $4.0 \%$ \\
\hline 8Year & 16 & $16.0 \%$ & 22 & $22.0 \%$ & 38 & $38 \%$ \\
\hline 9 Year & 25 & $25.0 \%$ & 14 & $14.0 \%$ & 39 & $39 \%$ \\
\hline 10 Year & 12 & $12.0 \%$ & 7 & $7.0 \%$ & 19 & $19.0 \%$ \\
\hline Total & 57 & $57.0 \%$ & 43 & $43.0 \%$ & 100 & $100.0 \%$ \\
\hline
\end{tabular}

Source: Primary Data, June 2019

Table 4 shows that almost half of the 43 respondents (43\%) who had negative behaviors prior to sexual education. Of the $43 \%$ who have negative behavior, a small percentage of 22 respondents $(22 \%)$ are 8 years old. And most of the 57 respondents $(57 \%)$ had positive behavior before sexual education. Of the $57 \%$ who have positive behavior, a small proportion of 25 respondents $(25 \%)$ are 9 years old.

c. The results of gender crosstabulation data with the behavior of respondents before sexual education

Table 5 sex crosstabulation data with respondent behavior before sexual education.

\begin{tabular}{lcccccc}
\hline \multirow{3}{*}{ Gender } & \multicolumn{3}{c}{ Respondent Behavior } & \multicolumn{2}{c}{ Total } \\
\cline { 2 - 6 } & \multicolumn{2}{c}{ Positive } & \multicolumn{2}{c}{ Negative } & & \\
\cline { 2 - 6 } & Frequency & Presentase & Frequency & Persentase & Frekuency & Persentase \\
\hline Male & 23 & $23.0 \%$ & 20 & $20.0 \%$ & 43 & $43.0 \%$ \\
\hline Famale & 34 & $34.0 \%$ & 23 & $23.0 \%$ & 57 & $57.0 \%$ \\
\hline Total & 57 & $57.0 \%$ & 43 & $43.0 \%$ & 100 & $100.0 \%$ \\
\hline
\end{tabular}

Source: Primary Data, June 2019

d. The results of data on age crosstabulation with respondent behavior after sexual education 
Table 6 data on age crosstabulation with respondent behavior after sexual education.

\begin{tabular}{lcccccc}
\hline \multirow{2}{*}{ Age } & \multicolumn{4}{c}{ Respondent Behavior } & \multicolumn{2}{c}{ Total } \\
\cline { 2 - 6 } & \multicolumn{2}{c}{ Positive } & \multicolumn{2}{c}{ Negative } & \multicolumn{2}{c}{} \\
\cline { 2 - 6 } & Frequency & Presentase & Frequency & Persentase & Frekuency & Persentase \\
\hline 7 Year & 4 & $4.0 \%$ & 0 & $0.0 \%$ & 4 & $4.0 \%$ \\
\hline 8 Year & 38 & $38.0 \%$ & 0 & $0.0 \%$ & 38 & $38 \%$ \\
\hline 9 Year & 37 & $37.0 \%$ & 2 & $2.0 \%$ & 39 & $39 \%$ \\
\hline 10 Year & 16 & $19.0 \%$ & 3 & $3.0 \%$ & 19 & $19.0 \%$ \\
\hline Total & 95 & $95.0 \%$ & 4 & $5.0 \%$ & 100 & $100.0 \%$ \\
\hline
\end{tabular}

Source: Primary Data, June 2019

Table 6 shows that almost all 95 respondents (95\%) had positive behavior after sexual education. Of the $95 \%$ who have positive behavior, almost half are 38 respondents $(38 \%)$ aged 8 years. And a small portion of 5 respondents $(5 \%)$ have negative behavior after sexual education. Of the $5 \%$ who have negative behavior, a small percentage of 3 respondents $(3 \%)$ are 10 years old.

e. The results of gender crosstabulation data with the behavior of respondents after sexual education

Table 7 sex crosstabulation data with respondent behavior after sexual education.

\begin{tabular}{lcccccc}
\hline \multirow{3}{*}{ Gender } & \multicolumn{3}{c}{ Respondent Behavior } & \multicolumn{2}{c}{ Total } \\
\cline { 2 - 5 } & \multicolumn{2}{c}{ Positive } & \multicolumn{2}{c}{ Negative } & & \\
\cline { 2 - 6 } & Frequency & Presentase & Frequency & Persentase & Frekluency & Persentase \\
\hline Male & 39 & $39.0 \%$ & 4 & $4.0 \%$ & 43 & $43.0 \%$ \\
\hline Famale & 56 & $56.0 \%$ & 1 & $1.0 \%$ & 57 & $57.0 \%$ \\
\hline Total & 95 & $95.0 \%$ & 5 & $5.0 \%$ & 100 & $100.0 \%$ \\
\hline
\end{tabular}

Source: Primary Data, June 2019

Table 7 shows that almost all 95 respondents (95\%) had positive behavior after sexual education. Of the $95 \%$ who have positive behavior, the majority are 56 respondents $(56 \%)$ are female. And a small portion of 5 respondents (5\%) have negative behavior after sexual education. Of the $5 \%$ who have negative behavior, a small percentage of 4 respondents (4\%) are male. f. Data from the analysis of the effect of sexual education on the prevention of sexual harassment using the Wilcoxon Signed Rank Test

Table 8 data analysis results of the influence of sexual education on the prevention of sexual harassment using the Wilcoxon Signed Rank Test.

Source: Primary Data, June 2019

\begin{tabular}{ccc}
\hline Uji & $\operatorname{Sig}(\rho)$ & Information \\
\hline Pre-post test eksperimen & 0,000 & Signifikansi \\
\hline
\end{tabular}

Based on the analysis of the effect of sexual education on the prevention of sexual harassment using the Wilcoxon Signed Rank Test in table 8 through SPSS for Windows with a significance level $\alpha=0.05$, the value $\rho=0.00$, which indicates that the value of $\rho(0.00)<\alpha$ (0.05) then H0 is rejected, meaning that there is an influence of sexual education on the prevention of sexual harassment in school-aged children at SD Darul Ulum Bungurasih Waru Sidoarjo. 
1. Behavior of respondents before sexual education

Based on table 3 shows that prevention efforts undertaken by respondents in the form of known behavior through the results of filling out the questionnaire before sexual education is obtained the minimum value or the smallest value of filling a questionnaire of 1 and the maximum value or the largest value of the results of filling out the questionnaire is 12 . Behavior of respondents before Sexual education was carried out, as shown in table 4, it is known that most of the 57 respondents $(57 \%)$ who behaved positively before sexual education were conducted and the results obtained were almost half of the 43 respondents $(43 \%)$ for the category of negative behavior prior to sexual education. Of the $43 \%$ who have negative behavior, a small percentage of 22 respondents $(22 \%)$ are 8 years old. Table 5 shows that of the $43 \%$ who have negative behavior, a small proportion of 23 respondents $(23 \%)$ are female.

Questionnaire consisting of 12 questions filled by 100 respondents answered a lot wrong on the question "when you can touch your body that is covered by clothes?", "Do our bodies have to be always guarded and protected", and "can you accept something from someone who is not Do you know?".

Education / education is defined as a process with certain methods so that people gain knowledge, understanding, and how to behave in accordance with needs (Muhibinsyah, 2017). Sexual education is to introduce children to sex and how to look after it both in terms of health and hygiene, security, and safety (Andika, 2010). Sexual education is not merely explaining about sex. Sexual education, like other education in general, which contains the transfer of values from educators to students. Thus, information about sex is not given "naked", but rather given "contextually", that is, in relation to the norms prevailing in society (Sarwono, 2011).

From the results obtained as discussed above, it can be concluded that almost half of respondents behave negatively before giving sexual education, which has a negative behavior before sexual education is a minority of 8 years old and most are female. We can know the behavior of respondents through questions that are answered incorrectly by respondents is a description that respondents prior to sexual education still do not know when they may touch the body covered with clothes, the importance of protecting and protecting their own body, and they also still do not know that they do not may receive something from just anyone or from people they don't know if they don't exist or aren't with their parents. One of the causes of the high number of respondents who have negative behavior before being given sexual education is because the school still does not have a School Health Business (UKS) and the school has never cooperated with the health, therefore there has never been an outreach or provision of health information at school the. Sexual education in this research is an introduction to sex or sex biologically to school-age children and the importance of protecting and protecting their own bodies in order to prevent undesirable things from happening. If children have received new information, automatically they also get new knowledge, the knowledge they have will greatly affect their attitudes and behavior. Someone's behavior or someone's behavior can be seen from the level of knowledge and the knowledge itself can be obtained from an education or education both formally and informally.

At school age children prefer to ask questions about many things and like to try new things for them to do. So it needs to be equipped with knowledge so that children can maintain and protect their own bodies. The theory states that delivery or provide sexual education to children must be in accordance with the level of his age or in accordance with the understanding of children, it needs to be underlined that if the child is left unaccompanied or without parental guidance in his developmental years the possibility of growth and development will not be in accordance with parental expectations. It could be that children 
will have sexual behavior that deviates or maybe the child will be a victim of sexual crimes because they are not equipped with knowledge or do not get guidance from the closest person. 2. Behavior of respondents after giving sexual education

Based on table 3 shows that prevention efforts undertaken by respondents in the form of known behavior through the results of filling out the questionnaire after sexual education is obtained the minimum value or the smallest value of filling out the questionnaire by 6 and the maximum value or the largest value of the results of filling out the questionnaire is 12 . Behavior of respondents after Sexual education was carried out as shown in table 6. It can be seen that almost all 95 respondents $(95 \%)$ were in the category of positive behavior after sexual education and it was found that a small portion of 5 respondents $(5 \%)$ was in the category of negative behavior after sexual education. Of the $95 \%$ who have positive behavior, almost half are 38 respondents (38\%) aged 8 years. Table 7 shows that $95 \%$ of those who have positive behavior, the majority are 56 respondents (56\%) are female. Questionnaire consisting of 12 questions filled by 100 respondents answered a lot correctly to the question "does our body have to be always guarded and protected?", "Can someone else hold the part of your chest and around your pants?", And "What would you do if there are other people who want to touch the chest or around your pants? ".

Prevention is an effort / effort in the form of behavior carried out by an individual in preventing the occurrence of something undesirable, in the broadest sense it is also interpreted as an intentional attempt made to prevent interference, damage, or loss for someone (Oktavia, 2013). The main domains or domains of human behavior are: knowledge, attitude, and practice (Notoatmodjo, 2010). Prevention can be through health education / education in the community, identifying risk factors, and detecting actual events to take action and prevent similar events in the future (Humphreys and Campbell, 2011). Behavior change as a goal of promotion or education which has 3 dimensions, namely, changing negative behavior into positive, developing positive behavior, and maintaining behavior that is positive or in accordance with norms or values (Purwoastuti \& Walyani, 2015).

The expectation of researchers is that all respondents can change their negative behavior into positive towards preventing sexual harassment, but there are still some respondents whose behavior is negative, the possible cause is due to lack of time to carry out educational provision so that all respondents are only collected in one room and only become a large group that can cause their concentration or level of focus to be reduced or disrupted because researchers also find it difficult to control or control all respondents in the hundreds. From the results obtained as discussed in the section above, it can be concluded that almost all of the respondents behaved positively after giving sexual education, almost half of them had positive behaviors towards preventing sexual harassment after being carried out at 8 years of age and most were female. We can know that many questions answered correctly by respondents are an illustration that the respondents after sexual education have known the importance of protecting and protecting themselves, knowing that other people should not hold the chest or around their pants, and also they already know what they should do if there is someone who wants to touch the chest or around their pants. Prevention of sexual harassment is made as an effort to prevent something intentionally so that undesirable things do not occur, which can damage, and harm someone, especially for children who will be the nation's next generation and still have a long future to live. Sexual education on the prevention of sexual harassment carried out in this study uses methods that are attractive to children so as not to cause boredom to them and they can pay attention to and then understand the contents contained therein. Playing an animated cartoon movie video as an educational medium in which there are many lessons aimed at educating respondents, and it is evident that the spectacle presented in the 
form of audio visual is able to attract the attention of respondents, respondents look very enthusiastic to watch and listen seriously at the start of the screening video to completion.

The effect of sexual education on the prevention of sexual harassment of respondents.

Based on the results of the analysis of the influence of sexual education on the prevention of sexual harassment using the Wilcoxon Signed Rank Test in table 5.8. through SPSS shows the value of $\rho=0.00$ and the value of $\alpha=0.05$ which means that the value of $\rho(0.00)<\alpha(0.05)$, then $\mathrm{HO}$ is rejected, meaning there is an influence of sexual education on the prevention of sexual harassment in school-age children at SD Darul Ulum Bungurasih Waru Sidoarjo.

In theory, a change in behavior of a person accepts or adopts a new behavior in his life through three stages, the first stage is the change in knowledge which before a person adopts a new behavior, he must know in advance the benefits of the behavior for himself or his family. The second stage is attitude which is a response that is still closed from someone to a stimulus or object. And the stage of an action or behavior is an attitude that has not been automatically realized in an action, to manifest it into an actual action it needs supporting factors and facilities (Purwoastuti \& Walyani, 2015).

It can be concluded that a person's behavior will change after getting information or knowledge, but it will not materialize into a real behavior if there is no inner will to make a change and also does not get support from outside such as family or closest people around him. We as nurses are tasked to examine firsthand the knowledge of someone we will give information before giving information both to the family and to the person concerned directly namely children so that they get the right information from the right source not from a source that cannot be accounted for.

\section{Conclusion}

1. Elementary students at Darul Ulum Bungurasih Waru Sidoarjo found that almost half of them behaved negatively before sexual education was conducted.

2. Elementary students at Darul Ulum Bungurasih Waru Sidoarjo found that almost all of them behaved positively after sexual education.

3. There is an influence of sexual education on the prevention of sexual harassment in school-aged children at SD Darul Ulum Bungurasih Waru Sidoarjo. Students who have received sexual education have positive behaviors towards the prevention of sexual harassment

\section{Referensi}

[1] Adesola A. Ogunfowokan and Reuben B. Fajemilehin. 2012. Impact of a School-Based Sexual Abuse Prevention Education Program on the Knowledge and Attitude of High School Girls. The Journal of School Nursing. 28 (6): 459-468.

[2] Andika, Alya. 2010. Bicara Seks Bersama Anak. Yogyakarta: Pustaka Anggrek.

[3] Anugrah Sulistiyowati, Andik Matulessy, dan Herlan Pratikto. 2018. Psikoedukasi Seks: Meningkatkan pengetahuan untuk Mencegah Pelecehan Seksual pada Anak Prasekolah. Jurnal Ilmial Psikologi Terapan. 06 (01): 17-24. 
[4] Budi Anna, Keliat. 2016. Keperawatan Kesehatan Jiwa Stuart. Jakarta: Salemba Medika.

[5] Chandra, Budiman. 2008. Metodologi Penelitian Kesehatan. Jakarta: EGC.

[6] Chomaria, Nurul. 2014. Kenali dan Tangani Pelecehan Anak. Solo: Tata Medina.

[7] Dharma, Kusuma Kelana. 2011. Metodologi Penelitian Keperawatan. Jakarta: CV. Trans Info Media.

[8] El-Qudsy, Hasan. 2012. Ketika Anak Bertanya Tentang Seks. Cet. I. Solo: Tinta Medina.

[9] Faturrahman et al,. 2012. Pengantar Pendidikan. Jakarta: Prestasi Pustaka Publisher.

[10] Fauzi'ah, Syarifah. 2016. Faktor Penyebab Pelecehan Seksual Terhadap Anak. Volume IX Nomor 2.

[11] Hastuti, S. (2014). Pendidikan Seksual Anak di TK dan SD. disampaikan dalam Seminar Sanata Dharma Berbagi, Yogyakarta, 8 September 2014.

[12] Hedmi, Yoli. 2010. Terhindar dari Pelecehan Seksual. Jakarta: ISBN.

[13] Heggen, Caroyn Holderread. 2008. Pelecehan Seksual dalam Keluarga Kristen dan Gereja. Jakarta: Gunung Mulia.

[14] HIMPSI. (2010). Kode Etik Psikologi Indonesia. Jakarta : HIMPSI.

[15] Indriati, E. (2014). Badanku Milikku. Jakarta : Gramedia Pustaka Utama.

[16] Jatmikowati, Tri Endang, Ria Angin, dan Ernawati. 2015. Model dan Materi Pendidikan Seks Anak Usia Dini Perspektif Gender Untuk Menghindarkan Sexual Abuse. Cakrawala Pendidikan. 34 (03): 434-448.

[17] Kusumaningtyas, AD dan Ahmad Nurcholis dkk. 2015. Seksualitas dan Agama: Kesehatan Reproduksi dalam Perspektif Agama-Agama. Jakarta: Gramedia.

[18] Machsun. 2016. the Effectiveness Of Education On Secondary Sex Characteristics to the Knowledge Of Teenagers (female) in V grade of SDN Campurejo City Kediri. Jurnal Ners dan Kebidanan. 03(03): 189-192.

[19] Mohammad Tegar Indrayana. 2017. Profil Kasus Kekerasan Seksual terhadap Perempuan dan Anak yang Diperiksa di Rumah Sakit Bhayangkara Dumai (2009-2013). Jurnal Kesehatan Melayu. 001 (01) halaman: 9-13.

[20] Muhibinsyah. 2017. Psikologi Pendidikan dengan Pendekatan Baru. Bandung: PT Remaja Rosdakarya Offset.

[21] Notoatmodjo, Soekijdo. 2012. Metodologi Penelitian Kesehatan. Jakarta: Rienka Cipta.

[22] Nursalam. 2011. Konsep dan Penerapan Metodologi Penelitian Ilmu Keperawatan: Pedoman Skripsi, Tesis, dan InstrumenPenelitian Keperawatan Edisi 2. Jakarta: Salemba Medika

[23] Nugraha, Boyke Dian dan Sonia Wibisono. 2016. Adik Bayi Datang Dari Mana? A-Z Pendidikan Seks Usia Dini. Jakarta: Mizan Publika.

[24] Nursalam. 2015. Manajemen Keperawatan: Aplikasi dalam Praktik Keperawatan Profesional Edisi 5/Nursalam. Jakarta: Salemba Medika.

[25] Purwoastuti, Endang, dan Elisabeth Siwi Walyani. 2015. Perilaku dan softskills kesehatan. Yogyakarta: Pustakabarupress.

[26] Pietter, Herri Zan, Bethsaida Janniwarti, dan Marti Saragih. 2011. Pengantar Psikopatologi untuk Keperawatan. Jakarta: Kencana.

[27] Sarwono, Sarlito W. 2011. Psikologi Remaja. Jakarta: Rajawali Pers.

[28] Sugiyono. 2009. Metodologi Penelitian Kuantitatif, Kualitatif dan R\&D. Bandung: Alfabeta.

[29] Supartini, Yupi. 2012. Buku Ajar Konsep Keperawatan Anak. Jakarta: EGC.

[30] Supriyanto, Ahmad dan Afifah Afra. 2011. Pendidikan Seks untuk Remaja. Surakarta: Gizone Publishing.

[31] Triwiyanto, Teguh. 2014. Pengantar Pendidikan. Jakarta: Bumi Aksara.

[32] Widyanto, Faisal Candra. 2014. Keperawatan Komunitas dengan Pendekatan Praktis. Yogyakarta: Nuha Medika.

[33] Sri Puji Lestari, Dwi Indah Iswanti, and Son Haji. 2017. Optimizing Sexuality Education in Early Childhood Based on Puppet Show. Health Notion. 01 (04): 321-323. 